\title{
Disaster education through the adaptation of the werewolf game and acehnese local wisdom
}

\author{
Ghazi Maulana ${ }^{1}$, Uswatun Hasanah², Salwa Hanum $^{3}$, Syifa Urrahmi³ ${ }^{3}$ Teuku Afzal Dzikri³, and Rina Suryani Oktari ${ }^{4 * 1}$ \\ ${ }^{1}$ Faculty of Medicine, Syiah Kuala University, Banda Aceh \\ ${ }^{2}$ Faculty of Dentistry, Syiah Kuala University, Banda Aceh \\ ${ }^{3}$ Faculty of Industrial Engineering, Syiah Kuala University, Banda Aceh \\ ${ }^{4}$ Tsunami \& Disaster Mitigation Research Centre (TDMRC) and Department of Family Medicine, Faculty of Medicine, Universitas \\ Syiah Kuala, Banda Aceh
}

\begin{abstract}
Aceh is one of the provinces in Indonesia that is vulnerable to several disasters caused by natural hazards. The earthquake and tsunami in 2004 have given considerable losses to the people of Aceh and impacted people's lives and education process. Some of the impacts include the deaths of tens of thousands of students and teachers and 1,488 schools damaged, which disrupted the education process of 150,000 students. In addition, the people of Aceh are also faced with disasters caused by non-natural hazards, namely is the coronavirus disease (COVID-19) pandemic. Aceh has local wisdom, such as Rumoh Aceh, patchouli, jamblang, and Nandong Smong, which has been known from ancient times across generations and has been proved by research for their benefits in disaster mitigation. This study had developed a game to introduce disaster mitigation combined with local wisdom in Aceh called Serigala Siaga Bencana (SERGANA), adopted and modified from the werewolf game. The validity test of this game involved 15 students from Dayah Darul Hikmah, who were then fostered as a team of students for disaster preparedness with knowledge, understanding, and practice of preparedness in dealing with disasters. The results showed an increase in the score from pre-test to post-test after playing the game SERGANA.
\end{abstract}

\section{Introduction}

The 2004 tsunami caused considerable losses to the people of Aceh. This incident had an impact on people's lives and the implementation of education, including killing tens of thousands of students and teachers. In addition, 1,488 schools were damaged, causing around 150,000 students to be disrupted in their educational process [1].

Currently, the people of Aceh are also faced with disasters caused by non-natural hazards, namely is the coronavirus disease (COVID-19) pandemic. Based on data until September 12, 2021, the number of confirmed cases reached 35,909 people, with 5,879 people treated, 28,337 people recovered, and 1,693 people died in Aceh [2]. The occurrence of earthquakes and tsunamis in the era of the COVID-19 pandemic will undoubtedly have an increasingly lousy impact on the community.

Aceh has local wisdom which based on research by experts, has various benefits in anticipating potential disasters such as Rumoh Aceh, patchouli, jamblang, and Nandong Smong from Simeulue, which have been known for generations [3-5]. Local wisdom is very suitable to be adopted and used to preserve and introduce Acehnese culture to the community, especially millennials who have been distracted by globalization [6].

Dayah is one of the educational institutions that has a great influence on the lives of the Acehnese people. This is because the dayah has a role in building the Acehnese community, conveying Islamic da'wah, and educating the santri in Aceh. The uniqueness of the dayah in providing Islamic values is very relevant to the times, without destroying the local culture and language [7].

Dayah Darul Hikmah is one of the educational institutions in Aceh which is about 1,4 kilometers from the coast. In the 2004 tsunami incident, all the facilities and infrastructure owned by dayah were destroyed entirely. As a result, all students/santri and teachers and Ustaz-ustazah who served in this dayah also died. Lack of knowledge and preparedness in dealing with disasters is the main factor that causes many casualties. Based on the results of observations and interviews with the leaders of the dayah, it is known that disaster education or socialization has never been carried out and there are no disaster mitigation facilities and infrastructure. Therefore, systematic and integrated efforts are needed to carry out mitigation and preparedness in anticipating

\footnotetext{
${ }^{*}$ Corresponding author: okta@unsyiah.ac.id
} 
disasters in Dayah Darul Hikmah, especially during the COVID-19 pandemic.

This study aims to develop a game-based method to provide education to improve preparedness and disaster risk reduction. This method was adapted from a werewolf game that was modified to contain elements of disasters. The application of this method is expected to increase the attractiveness and understanding of students about disasters. In addition, this method also adds an element of knowledge and the role of several institutions directly involved in disasters. The game can be played both offline and online. Thus, in addition to entertaining, this game can also increase the knowledge of the players about disasters.

\section{Methods}

This study uses a Research and Development (R\&D) approach to produce a disaster education game that adopts the werewolf game and local wisdom in Acehnese. The method developed is in the form of the Serigala Siaga Bencana or abbreviated as SERGANA. Game testing was carried out at Dayah Darul Hikmah, a boarding school located very close to the beach, approximately 1.4 kilometers. The location of Dayah Darul Hikmah is located in the red zone, which indicates the area is vulnerable and at high risk of being hit by a tsunami. As a result, 15 students of dayah were fostered as a team of santri for disaster preparedness playing this game accompanied by providing education on knowledge, understanding, and practice of preparedness in dealing with disasters. After the students played the game and gave the education, it was continued with the measurement of knowledge in the students through posttest work.

Research and development approaches of Borg and Gall (1989) were used in the process of developing SERGANA [8]. This study involved only three (see Figure 1) of the total 10 steps proposed by Borg and Gall, namely: i) Preliminary study, ii) Model's development, and iii) Model's testing.

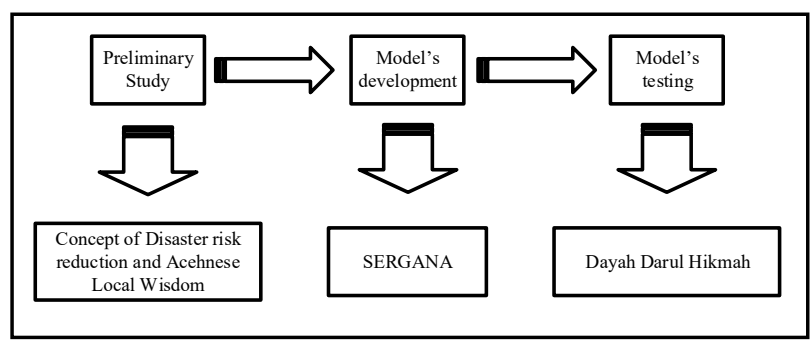

Fig. 1. Research and Development Process of the study. (Source: Modified from Borg and Gall, 1989)

\section{Result and discussion}

\subsection{The concept of SERGANA}

This study has developed a game to introduce disaster mitigation combined with local wisdom in Aceh named Wolf Prepared for Disaster or Serigala Siaga Bencana (SERGANA). This game was adopted and modified from the werewolf game so that it is suitable for playing both offline and online. In addition to entertaining, this game would also increase the knowledge of the players regarding disasters. Six to 12 people can play this game. Players in this game are divided into five major roles. Role I is the "Moderator" who directs the game and explains what the players are doing. Role II is "BMKG" who knows the role of one of the players when it is his turn. BMKG is Meteorology, Climatology, and Geophysics Agency, a government agency that conveys information and early warnings to related agencies and the public regarding disasters. Role III is "BNPB" that protects one of the players or itself from the threat of disaster. BNPB is the National Agency for Disaster Management, a government agency tasked with coordinating disaster management. Role IV is "Disaster", which consists of tsunamis, earthquakes and COVID-19. All disaster roles know each other but can only launch one type of disaster on other players, which disaster is determined randomly. Role V is "Citizen", who is the community, which will perform the disaster mitigation.

This game introduces several disaster mitigation efforts-First, Nandong Smong's Song (tsunami alert). Nandong Smong is one of the local wisdoms from Simelue-Aceh in dealing with the tsunami disaster $[9,10]$. Nandong Smong is a traditional art that is very popular among the people of Simeulue, which contains education on preparedness in dealing with the tsunami [11-13]. Second, establishing Rumoh Aceh (Acehnese traditional house). Rumoh Aceh is determined to have a role in disaster mitigation. Previous research using observations on the Rumoh Aceh model mockup concluded that Rumoh Aceh is earthquake-resistant [4]. This is because the structural elements are able to respond to earthquakes in longitudinal and transverse directions, which are determined by a relationship that forms the construction in the legs, body, and head area $[14,15]$. Third, consuming jamblang (syzygium cumini) and processed patchouli (health supplements) Based on various studies, it is said that patchouli and jamblang have multiple health benefits. For example, patchouli is often used as a traditional medicine that functions as an antidepressant, decongestant, headache medicine, antiinflammatory, anti-inflammatory, antiasmatic, antimicrobial and others $[5,16]$. Jamblang also contains antioxidants close to vitamin C with IC50 score of 8.85, which is categorized as very active antioxidants, which increase the body's immunity and functions as anti-viral, anti-bacterial, anti-asthmatic, anti-allergic, infectious drugs, and others [3,17].

In addition, the SERGANA game also has a disaster preparedness mode and a post-disaster mode that residents can choose directly. Preparedness mode consists of: i) preparing shelter in a place that feels strong to avoid building debris such as under tables and others when an earthquake strikes, ii) following directions when a Tsunami occurs, iii) using health protocols and iv) avoiding when the Covid-19 pandemic strikes [18-19]. While the post-disaster modes include i) staying away from buildings, ii) staying away from the coast, and iii) doing self-isolation $[18,20]$. Residents who choose a package that is suitable for the disaster 
will be declared safe. Through this game, it is hoped that it can increase students understanding of disaster mitigation science with local wisdom in Aceh. This game is also a fun and entertaining learning tool without feeling overwhelmed. This game is expected to continue to increase its existence and spread to other circles, so that knowledge about disaster mitigation can spread more quickly.

\subsection{Result of model development of SERGANA}

Several activities have been carried out at the SERGANA development stage, including discussing the method of implementing the SERGANA game with BPBA (Aceh Disaster Management Agency), Dinas Dayah, and teachers, conducting a pretest to test the level of knowledge related to disasters, small-scale group trials, post-test, large-scale game testing, and product improvement.

Table 1. Pretest and Post-test score

\begin{tabular}{|c|l|l|c|c|c|}
\hline No & $\begin{array}{l}\text { Initial } \\
\text { Name }\end{array}$ & $\begin{array}{c}\text { Gra } \\
\text { de }\end{array}$ & $\begin{array}{c}\text { Pretest } \\
\text { (\%) }\end{array}$ & $\begin{array}{c}\text { Post- } \\
\text { test } \\
\mathbf{( \% )}\end{array}$ & $\begin{array}{c}\text { Post- } \\
\text { test/Pr } \\
\text { e-test } \\
\mathbf{( \% )}\end{array}$ \\
\hline 1 & AA & $8-1$ & 55 & 70 & 27,27 \\
\hline 2 & AH & $8-2$ & 55 & 85 & 54,55 \\
\hline 3 & AN & $8-1$ & 45 & 55 & 22,22 \\
\hline 4 & FA & $8-2$ & 60 & 75 & 25 \\
\hline 5 & H & $7-1$ & 65 & 80 & 23,08 \\
\hline 6 & KPM & $8-2$ & 70 & 75 & 7,14 \\
\hline 7 & KK & $8-1$ & 60 & 90 & 50 \\
\hline 8 & NM & $8-1$ & 65 & 85 & 30,77 \\
\hline 9 & NAA & 8.1 & 65 & 85 & 30,77 \\
\hline 10 & RA & $8-2$ & 70 & 90 & 28,57 \\
\hline 11 & RP & $8-1$ & 65 & 85 & 30,77 \\
\hline 12 & RT & $7-1$ & 40 & 75 & 87,5 \\
\hline 13 & SAY & 8.3 & 50 & 75 & 50 \\
\hline 14 & SM & $7-2$ & 30 & 75 & 150 \\
\hline 15 & TH & $7-3$ & 35 & - & - \\
\hline \multicolumn{3}{|c|}{ Average (\%) } & 55,33 & 78,57 & 42,00 \\
\hline
\end{tabular}

SERGANA consists of several modes and two phases, namely the Preparation phase and also the News phase. Every time the News phase arrives, all players discuss to determine which player is expelled for being accused of causing disaster through voting as a form of anticipation. At the same time, each phase of the Preparation of the Calamities designates one by one the players who will be hit by it. The game will end when a disaster hits all citizens or all Disasters have been eliminated from the game. Through the SERGANA game, we hope to add to the public's knowledge about disasters and introduce elements of Aceh's local wisdom.

\subsection{Test model of SERGANA}

The SERGANA game is played by 6 to 15 students who will be fostered as a disaster preparedness student team with knowledge, understanding, and preparedness practices in dealing with disasters. The game is carried out for 15-20 minutes so that the students: 1) guide the game; 2) plays the role well; 3) know the flow of the game from beginning to end. This game can be played anywhere by students.

The development of the SERGANA game which was adapted from the werewolf game, provides benefits for the students who play it. One of the students who joined the team said:

"This game is fun and exciting because I can directly play the role and know the institutions in disaster as well as local wisdom from Aceh itself. This game can also be played by my friends and I in our spare time".

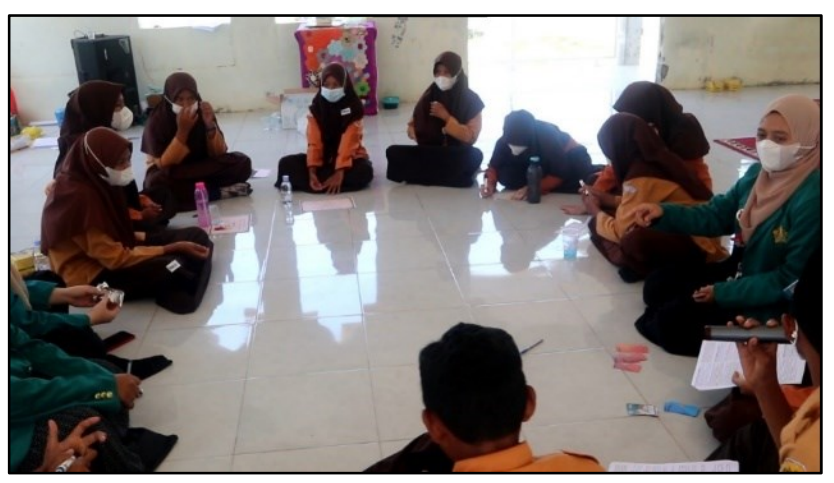

Fig. 2. Students Playing SERGANA at Dayah Darul Hikmah. (Source: Author Documentation)

In addition, the school is also grateful to the implementers of SERGANA because students have good knowledge of local Aceh wisdom such as nandong smong, rumoh aceh, jamblang, and patchouli as well as institutions related to disasters so that they can increase their preparedness against earthquake, tsunami, and Covid-19. The SERGANA game consists of several phases, as described in the Table 2.

Table 2. SERGANA game phase.

\begin{tabular}{|l|l|}
\hline \multicolumn{1}{|c|}{ Phase } & \multicolumn{1}{c|}{ Description } \\
\hline $\begin{array}{l}\text { Preparation } \\
\text { Phase }\end{array}$ & $\begin{array}{l}\text { In this phase, the moderator directs the } \\
\text { players by giving each player a role } \\
\text { card and giving instructions according } \\
\text { to the role they get }\end{array}$ \\
\hline $\begin{array}{l}\text { News } \\
\text { Phase }\end{array}$ & $\begin{array}{l}\text { This phase provides information about } \\
\text { what players have been eliminated } \\
\text { when the preparation phase is } \\
\text { complete along with other additional } \\
\text { information. }\end{array}$ \\
\hline $\begin{array}{l}\text { Discussion } \\
\text { Phase }\end{array}$ & $\begin{array}{l}\text { In this phase the players are given time } \\
\text { to have discussions to determine which } \\
\text { players will be eliminated }\end{array}$ \\
\hline $\begin{array}{l}\text { Elimination } \\
\text { Phase }\end{array}$ & $\begin{array}{l}\text { In this phase the moderator directs } \\
\text { players to vote for players to be } \\
\text { eliminated }\end{array}$ \\
\hline $\begin{array}{l}\text { Victory } \\
\text { phase }\end{array}$ & $\begin{array}{l}\text { This phase determines the victorious } \\
\text { player who wins between the disaster } \\
\text { and the citizens }\end{array}$ \\
\hline
\end{tabular}




\section{Conclusion}

This study has developed an attractive, sustainable concept of disaster education and adapts Aceh local wisdom through the SERGANA game which is modified from the werewolf game. The development of the SERGANA game adopted from the werewolf game can be used as an indicator to enhance the role of local wisdom, such as nandong smong, rumoh aceh, jamblang and patchouli in the disaster education and pandemic mitigation model. This research is the initial stage of the development of SERGANA using a qualitative approach. SERGANA quantitative evaluation of development effectiveness is a study that will be carried out in the next step. The results showed an increase in the score from pre-test to post-test after playing the game SERGANA, which was $42 \%$.

Acknowledgments. The authors would like to give the sincerest gratitude to Dayah Darul Hikmah for continuous support and the warm welcoming. This study is part of the program funded by the Indonesian Ministry of Research, Technology, and Higher Education 2021.

\section{References}

1. Syamsidik, R.S. Oktari, A. Nugroho, M. Fahmi, A. Suppasri, K. Munadi, R. Amra, Fifteen years of the 2004 Indian Ocean Tsunami in Aceh-Indonesia: Mitigation, preparedness and challenges for a long-term disaster recovery process. International Journal of Disaster Risk Reduction, 54, 102052 (2021)

2. Pemerintahan Aceh. Info COVID-19. URL: https://covid19.acehprov.go.id. Accessed on 20th May 2021 (2021)

3. S. Nurhalisa, I. Ibrahim, I.A.P. Paerah, Formulasi Kapsul Daun dan Biji Jamblang (Syzigium cumini L.) sebagai Antioksidan Alami dari Desa Pallantikang Kabupaten Maros. Jurnal Medika Hutama, 2(2), 711-720 (2021)

4. E. Meutia, Pemetaan Sistem Struktur Konstruksi Rumah Tradisional Aceh dalam Merespon Gempa. Jurnal Arsitektur dan Perkotaan "KORIDOR", 8(1), 62-69 (2017)

5. M. Tahir, A. Muflihunna, Syafrianti, Penentuan Kadar Fenolik Total Ekstrak Etanol Daun Nilam (Pogostemon cablin Benth.) dengan Metode Spektrofotometri UV-VIS. Jurnal Fitofarmaka Indonesia, 4(1), 215-218 (2017)

6. D.K. Marjanto, B. Setiawan, S.D Kusumah, B. Utama , S. Biantoro, et al. Kearifan Lokal \& Lingkungan. 1st ed. Jakarta: PT GADING INTI PRIMA (2013)

7. Kantor Wilayah Kementerian Agama Provinsi Aceh. Sejarah Dayah. (2021)

8. W.R Borg and M. Gall. Education Research: An Introduction ( $4^{\text {th }}$ edition). New York. Logman publisher. (1989)

9. T. Husin. Kapita Selekta Hukum Adat Aceh Dan Qanun Wali Nanggroe. Revisi. Banda Aceh: Bandar Publishing (2016)
10. A. Kurniasih, J. Marin, R. Setyawan. Belajar dari Simeulue: Memahami Sistem Peringatan Dini Tsunami di Indonesia. J Geosains dan Teknol. 3(1):21 (2020)

11. I. Maulana, L. Raswita, S. Karlina, M.H.A Mukarram, R.S. Oktari. PASMINA: Arts-based tsunami education with an Islamic theme adopted from Nandong Smong. In IOP Conference Series: Earth and Environmental Science (Vol. 708, No. 1, p. 012094). IOP Publishing (2021)

12. R. H. Sari, T. Husin, Syamsidik, Kearifan Lokal Smong Masyarakat Simeuleu dalam Kesiapsiagaan Bencana 12 Tahun Pasca Tsunami. Jurnal Ilmu Kebencanaan (JIKA), 3(1), 27-32 (2016)

13. A.N. Gadeng, E. Maryani, E. Ningrum. The Simulation of Smong in Geography Learning to Enhance Understanding of Disaster. IOP Conf Ser Earth Environ Sci. Jun 28;286(1) (2019)

14. E. Meutia. Identifikasi Model Proporsi Bangunan Arsitektur Tradisional Aceh. In: Prosiding Seminar Kearifan Lokal dan Lingkungan Binaan. Medan; p. 145-55 (2017)

15. E. Meutia. Studi Sistem Struktur Dan Kontruksi Rumah Tradisional Aceh: di Daerah Pesisir Dan Pegunungan. In: Prosiding Seminar Nasional Kota dan Permukiman Lestari. Banda Aceh; (2015)

16. C.W. Li, X.L. Wu, X.N. Zhao, Z.Q. Su, H.M. Chen, X.F. Wang, et al. Anti-inflammatory property of the ethanol extract of the root and rhizome of Pogostemon cablin (Blanco) benth. Sci World J. 2013;(2013)

17. A.N. Sari. Potensi Antioksidan Alami pada Ekstrak Daun Jamblang (Syziguym cumini (L.) Skeels). Eksakta. ;18(2):107-12. (2017)

18. Badan Nasional Penanggulangan Bencana. Buku Saku Tanggap Tangkas Tangguh Menghadapi Bencana. Jakarta Timur: Pusat Data Informasi dan Komunikasi Kebencanaan BNPB; (2020)

19 Kepala Subdit KIE Kesehatan, Kepala Seksi Strategi Komunikasi Kesehatan, Kepala Seksi Penyebarluasan Informasi Kesehatan, Damawanti B, Rabina T, Sinansari, et al. Tanya Jawab Seputar Virus Corona. Jakarta: Kementerian Kesehatan RI, Direktorak Jendral, Direktoran Promosi Kesehatan dan Pemberdayaan Masyarakat; (2020)

20 M. Yahya, F. Fathahillah, R. Megavitry. Penerapan Alat Cuci Tangan Guna Pencegahan Penyebaran Virus COVID-19 di Desa Lagaruda. Dedikasi. 22(2):143-7 (2020) 